\title{
SYNTHESIS, CHARACTERIZATION AND ANTIBACTERIAL STUDIES OF AMINOBENZOTHIAZOLE DERIVATIVE AND ITS COPPER(II) COMPLEX
}

\author{
S. B. Rahardjo ${ }^{1,2,} \bowtie$, M. K. Widowati ${ }^{1}$, Y. A. Rasyda ${ }^{1}$, S.D. Marliyana ${ }^{1,2}$ \\ ${ }^{1}$ Department of Chemistry, Graduate Program, Faculty of Mathematics and Natural Sciences, \\ Sebelas Maret University, Surakarta, Indonesia \\ ${ }^{2}$ Department of Chemistry, Faculty of Mathematics and Natural Sciences, Sebelas Maret \\ University, Surakarta, Indonesia \\ ${ }^{\circledR}$ Corresponding Author: sentotbr@staff.uns.ac.id
}

\begin{abstract}
This research aimed to synthesize and characterize Schiff base ligand (SB) derived from 2-aminobenzothiazole with o-anisaldehyde and its $\mathrm{Cu}$ (II) complex and investigate their antibacterial activities. The complex (Cu(II)-SB) was synthesized in a mole ratio of 1:2 of metal to the ligand. The complex's physical measurements included UV-Vis, Atomic Absorption Spectrophotometer (AAS), Thermogravimetric Analysis/Differential Thermal Analysis (TG/DTA), FTIR, electrical conductivity, and magnetic susceptibility. The formation of the complex was indicated by a shift in the maximum wavelength of UV-Vis spectra toward smaller, from $823 \mathrm{~nm}$ for $\mathrm{Cu}$ (II) to $731 \mathrm{~nm}$ in the complex. The proposed complex formula was $\left[\mathrm{Cu}(\mathrm{SB})_{2}\right] \mathrm{SO}_{4} \cdot \mathrm{H}_{2} \mathrm{O}$. The IR spectral data on the $\mathrm{Cu}(\mathrm{II})-\mathrm{SB}$ showed that $\mathrm{SB}$ was coordinated through the $\mathrm{C}=\mathrm{N}_{\text {azomethine }}$ and $\mathrm{C}=\mathrm{N}_{\text {thiazole }}$ functional groups. The magnetic moment result $\mu_{\mathrm{eff}}$ of 2.07 B.M, indicated that the complex was paramagnetic and was expected to have square planar geometry. $\left[\mathrm{Cu}(\mathrm{SB})_{2}\right] \mathrm{SO}_{4} \cdot \mathrm{H}_{2} \mathrm{O}$ exhibited the highest antibacterial activity than the ligands and metals.

Keywords: Synthesis, Schiff Base, Copper, Complex, Aminobenzothiazole, Antibacterial.
\end{abstract}

RASĀYAN J. Chem., Vol. 14, No.3, 2021

\section{INTRODUCTION}

The search for new compounds with biological activity has been very much done, one of which is a complex compound. The complexes of the Schiff base ligands have received much attention due to their good biological activity for antibacterial, antifungal, and antioxidant. ${ }^{1-3}$ The Schiff base is a compound that has an azomethine $(\mathrm{C}=\mathrm{N})$ bond formed by the condensation reaction of carbonyl compounds with primary amines under certain conditions and is known for its strong coordination ability as a ligand. ${ }^{4,5}$ Previous studies have shown that metal ions which are bound to Schiff base ligands are capable of increased biological activity. ${ }^{6}$ Complex synthesis with Schiff base ligand has attracted many researchers because chelate from $\mathrm{N}$ and $\mathrm{O}$ donor atoms can bind to metal ions and exhibit good antibacterial activity to develop drug compounds. ${ }^{7-8}$

Research conducted by Kolate et al. (2020) showed that metal complex compounds have higher antimicrobial activity than free metals and ligands. ${ }^{9}$ Aminobenzothiazole ligands and their derivatives have good biological activity as antimicrobials, anticancer, and antioxidants. ${ }^{10-11}$ Aminobenzothiazole is a benzothiazole derivative with a well-known heterocyclic group with good biological properties. Besides, benzothiazole shows increased activity when it is complexed with metals. ${ }^{12}$ Some aldehydes and ketones have good antibacterial properties, so the metal complex consists of Schiff bases derived from aldehydes, or ketones will form new compounds with higher biological activity. ${ }^{11}$

Various transition metals are biologically active compounds used for antibacterial compounds such as $\mathrm{Cu}$, $\mathrm{Ni}$, and Co. ${ }^{13}$ Among transition metals, copper is a widely studied metal because it is the third most abundant metal element in the human body, after iron and zinc. ${ }^{14}$

The progression of diseases is increasing due to the evolution of bacteria, which are increasingly resistant to drugs. The level of bacterial resistance that occurs can increase the risk of spreading infection, difficulty controlling infection, and can cause death. This concern underlies the search for new 
RASĀYAN J. Chem.

Vol. 14 | No. 3 |2116-2124| July - September | 2021

compounds that can deal with bacterial resistance. ${ }^{15}$ Therefore, this research aims to synthesize copper complex compound with Schiff base ligand (SB) derived from aminobenzothiazole and observe its biological activity.

\section{Material and Methods}

\section{EXPERIMENTAL}

Chemicals in this research were used directly without purification. The s analysis of SB was carried out using Infrared spectra, ${ }^{1} \mathrm{H}-\mathrm{NMR}$, and ${ }^{13} \mathrm{C}-\mathrm{NMR}$. Measurements of copper content were analyzed with Shimadzu AA-6650 Atomic Absorption Spectrophotometer. Electronic spectral data of $\mathrm{Cu}(\mathrm{II})$ solution and the complex solution were analyzed in the range of 400-800 $\mathrm{nm}$ using UV-Vis Lambda 25 Perkin Elmer spectrophotometer using methanol as solvent. Infrared spectra were recorded on an FTIR Prestige-21 Shimadzu spectrophotometer. Thermogram was recorded at a temperature in the range of 20 to $900^{\circ} \mathrm{C}$ with a heating rate of a $10{ }^{\circ} \mathrm{C} / \mathrm{min}$ on a TG/DTA Linseis STA PT-1600. The electrical conductivity was calculated by Jenway CE 4071 conductivity meter. Standard solutions and copper complex solutions were made at the same concentration $(0,001 \mathrm{M})$ in methanol.

\section{Synthesis of Schiff Base Ligand (SB)}

Synthesis of SB from 2-aminobenzothiazole and o-anisaldehyde was done by adding o-anisaldehyde solution (1 mmol; 0.136 grams; $3 \mathrm{~mL}$ methanol) dropwise on 2-aminobenzothiazole solution (1 mmol; 0,150 gram; $3 \mathrm{~mL}$ methanol). After stirring for 5 minutes, six drops of glacial acetic acid were added and stirred for an hour at room temperature. The reaction was monitored by TLC. After an hour, the solids appeared. The solids were filtered, then washed with methanol.

\section{Synthesis of $\mathrm{Cu}(\mathrm{II})$ Complex (Cu(II)-SB)}

Synthesis of $\mathrm{Cu}$ (II) complex with $\mathrm{SB}$ was carried out by adding $\mathrm{CuSO}_{4} \cdot 5 \mathrm{H}_{2} \mathrm{O}(0.124 \mathrm{~g}, 1 \mathrm{mmol})$ solution in methanol as solvent $(5 \mathrm{~mL})$ dropwise to SB solution $(0.266 \mathrm{~g}, 2 \mathrm{mmol})$ in methanol $(5 \mathrm{~mL})$ as solvent. The solution was then stirred without heating for 3 hours until blue solids were observed. The obtained solids were filtered and dried with a vacuum desiccator.

\section{Antibacterial Study}

Antibacterial activity tests of complex compounds were carried out by agar diffusion method by measuring bacterial inhibition. ${ }^{16}$ Four ATCC bacteria used in testing were Staphylococcus aureus, Staphylococcus epidermidis, Escherichia coli, and Pseudomonas aeruginosa. The antibacterial test instruments were first sterilized by heating using an autoclave at $121^{\circ} \mathrm{C}$ at a pressure of 15 psi (per square inch) for 15 minutes. Agar Muller Hinton's media was dissolved in water, and the mixture was heated on a water bath while stirring with a magnetic stirrer.

The media suspension was inserted into the petri dish until it becomes solid. The bacterial suspension was made by dissolving a bacterial loop in sterile $9 \% \mathrm{NaCl}$. The compound solution was diluted using DMSO solvent with various concentrations. A compound solution with each concentration was dropped on $10 \mu \mathrm{L}$ paper disks using a micropipette. The bacterial suspension was etched evenly on the surface of the media suspension. Chloramphenicol was placed on media as a positive control and DMSO as a negative control. The paper disk's location was spaced with one another, then incubated for 24 hours at $37^{\circ} \mathrm{C}$. The inhibition of bacterial growth was known by measuring the clear zone's diameter around the test sample.

\section{Synthesis of Schiff Base Ligand (SB)}

\section{RESULTS AND DISCUSSION}

Synthesis of Schiff base compounds was carried out by reacting o-anisaldehyde with 2aminobenzothiazole in a mole ratio of $1: 1$ and by adding glacial acetic acid catalyst at room temperature for 3 hours. TLC test was performed to determine whether SB had formed. The eluents used were Nhexane: ethyl acetate $=8: 2$. TLC analysis was carried out to ensure no other compounds were formed so that the Schiff base ligand produced a single spot-on TLC. The Rf value of this base Schiff ligand was 0.76. The reaction scheme of SB formation is shown in Fig.-1. 


\section{RASĀYAN J. Chem.}

Vol. 14 | No. 3 |2116-2124| July - September | 2021<smiles>CCNCc1nc2ccccc2s1</smiles>

2-Aminobenzothiazole

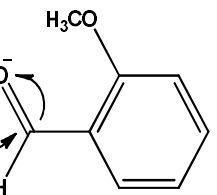

o-Anisaldehyde
$\mathrm{RT}, \mathrm{CH}_{3} \mathrm{COOH}$

$-\mathrm{H}_{2} \mathrm{O}$<smiles>COc1ccccc1/C=N/c1nc2ccccc2s1</smiles>

Schiff base ligand

Fig.-1: Reaction Scheme, Formation of Schiff Base Ligand (SB)

From the ${ }^{1} \mathrm{H}-\mathrm{NMR}$ proton data (Fig.-2), a chemical shift at $8.69 \mathrm{ppm}$ shows an azomethine proton. ${ }^{17}$ At a chemical shift of 6-8 ppm, the multiplet signal indicates the aromatic ring proton. The absence of a chemical shift with a broad peak at 1-2 ppm, a shift from the proton amine, shows that the Schiff base ligand has formed through the carbonyl and the amine group. ${ }^{13}$ C-NMR spectrum (Fig.-3) shows the number of carbon shifts corresponding to the number of carbon atoms in the Schiff base ligand and also shows a signal of $\mathrm{C}_{\text {azomethine }}$ at the $165.6 \mathrm{ppm} .{ }^{18}$



Fig.-2: ${ }^{1} \mathrm{H}-\mathrm{NMR}$ Spectrum of Schiff Base Ligand (SB)

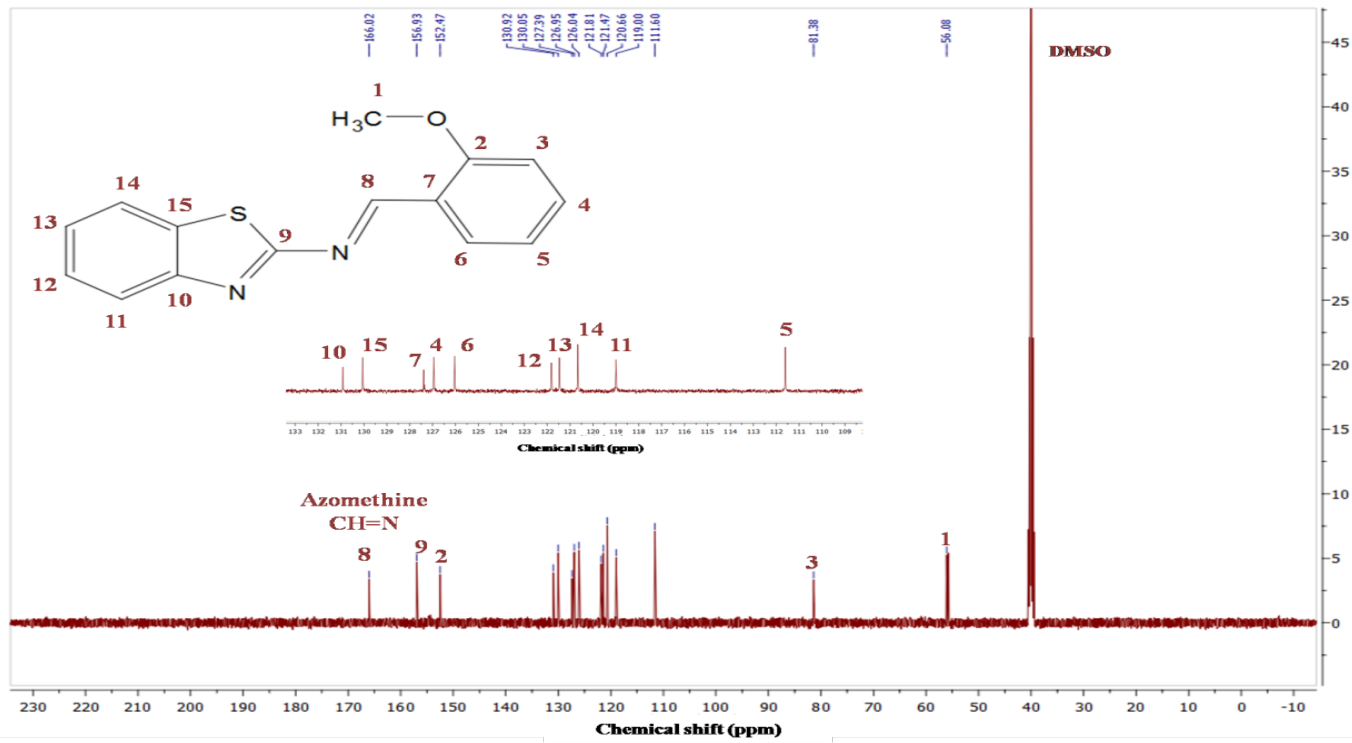

Fig.-3: ${ }^{13}$ C-NMR Spectrum of Schiff Base Ligand (SB) 


\section{RASĀYAN J. Chem.}

Vol. 14 | No. 3 |2116-2124| July - September | 2021

Analysis of SB was also performed using infrared spectroscopy. Infrared spectra of SB, 2aminobenzothiazole, and o-anisaldehyde can be seen in Fig.-4. There is no absorption of N-H belonging to aminobenzothiazole at 3394 and $3271 \mathrm{~cm}^{-1}$. Also, there is a loss of $\mathrm{C}=\mathrm{O}$ absorption corresponding to anisaldehyde at $1823 \mathrm{~cm}^{-1}$. These two groups disappear because aminobenzothiazole and o-anisaldehyde were reacted to form SB with the azomethine $(\mathrm{C}=\mathrm{N})$ group. This reaction is confirmed by the appearance of azomethine $(\mathrm{C}=\mathrm{N})$ absorption at $1604 \mathrm{~cm}^{-1} .{ }^{19}$ The infrared spectra results can strengthen the analysis that SB has been successfully formed.

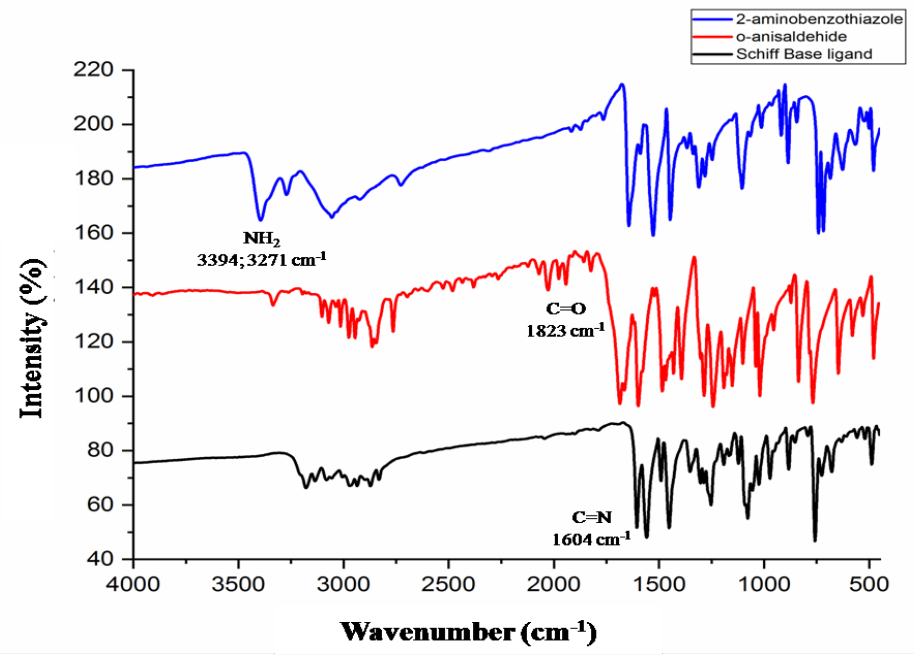

Fig.-4: FTIR Spectra of 2-aminobenzothiazole, o-anisaldehyde, and SB

\section{Synthesis of Cu(II)-SB Complex}

Synthesis of the complex was successfully carried out. The formed complex was indicated by a shift in the maximum wavelength towards the shorter one in the UV-Vis spectra ${ }^{20}$ from $823 \mathrm{~nm}$ to $778 \mathrm{~nm}$ as

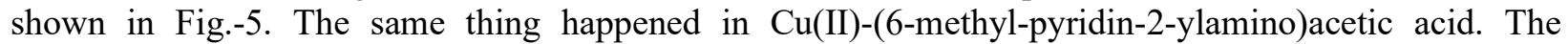
maximum wavelength shifted from $850 \mathrm{~nm}\left(\mathrm{CuCl}_{2} \cdot \mathrm{H}_{2} \mathrm{O}\right)$ to $775 \mathrm{~nm}$ in the complex. ${ }^{21}$
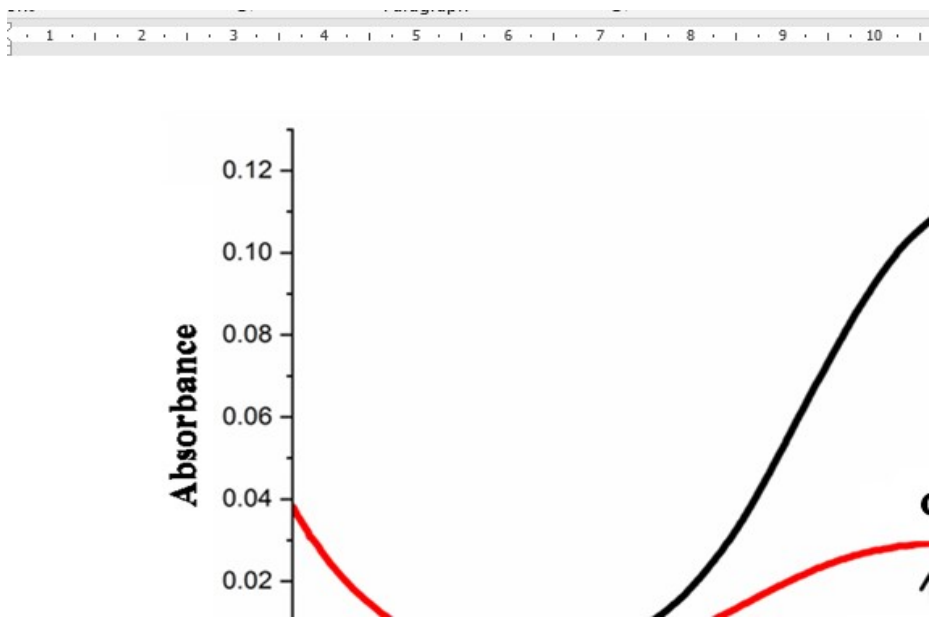

Fig.-5: Electronic Spectra of the Metal and the Complex

\section{Determination of Empirical Formula of the Complex}

AAS result showed that $\mathrm{Cu}$ (II)-SB contains $9.05 \%$ of copper. Theoretical calculations in various complex formulas of $\mathrm{Cu}(\mathrm{II})-\mathrm{SB}$ were compared with the AAS result. (Table-1). Thus, the complex formula can be estimated to be $\mathrm{Cu}(\mathrm{SB})_{2}\left(\mathrm{SO}_{4}\right)\left(\mathrm{H}_{2} \mathrm{O}\right)_{\mathrm{n}}(\mathrm{n}=0,1$, or 2$)$.

The thermogram of $\mathrm{Cu}(\mathrm{II})-\mathrm{SB}$ is presented in Fig.-6. The thermogram of the complex showed a decrease in mass at a temperature of $30-160{ }^{\circ} \mathrm{C}$ accompanied by an endothermic peak at $160{ }^{\circ} \mathrm{C}$. The mass 
RASĀYAN J. Chem.

Vol. 14 | No. 3 |2116-2124| July - September | 2021

reduction that occurs in the $\mathrm{Cu}(\mathrm{II})$-SB complex is $3.15 \%$ equivalent to the release of one $\mathrm{H}_{2} \mathrm{O}$ molecule (calc. $2.5 \%$ ). $\mathrm{H}_{2} \mathrm{O}$ molecules that were uncoordinated to the complex and have a position as crystal water will begin to decompose at a temperature of $10-170^{\circ} \mathrm{C}$, while $\mathrm{H}_{2} \mathrm{O}$ molecules that coordinate with the complex will begin to decompose at temperatures of $150-220{ }^{\circ} \mathrm{C} .{ }^{22}$ This also occurs in other complexes, such as the $\mathrm{Cu}(\mathrm{II})$ complex with the nicotinohydrazide derivative Schiff base ligand, which experiences the release of one $\mathrm{H}_{2} \mathrm{O}$ molecule as crystal water at a temperature of $30-130{ }^{\circ} \mathrm{C} .{ }^{23}$ From the thermogram results and the calculation of the release of $\mathrm{H}_{2} \mathrm{O}$ molecules, the possible complex formula is $\mathrm{Cu}(\mathrm{SB})_{2} \mathrm{SO}_{4} \cdot \mathrm{H}_{2} \mathrm{O}$.

Table-1: AAS Result and the Possible Complex Formulas



Fig.- 6: TG/DTA Data of the Complex

The results of electrical conductivity measurements of standard and complex compounds in methanol are shown in Table-2. The number of ions of the complex can be determined by comparing the molar conductivity of a complex solution with a standard solution's molar conductivity. The molar conductivity value of $\mathrm{Cu}(\mathrm{II})-\mathrm{SB}$ complex approaches the electrical conductivity value of $\mathrm{CuSO}_{4} \cdot 5 \mathrm{H}_{2} \mathrm{O}$ solution with the ratio of cation: anion $=1: 1$, so the estimated complex formula formed is $\left[\mathrm{Cu}(\mathrm{SB})_{2}\right] \mathrm{SO} 4 \cdot \mathrm{H}_{2} \mathrm{O}$.

Table-2: Molar Conductivity of $1.10^{-3} \mathrm{M}$ Standard Solutions and the Complex in Methanol

\section{Infrared Analysis}

\begin{tabular}{c|c|c|c}
\hline Compounds & $\begin{array}{c}\text { Molar Conductance } \\
\Lambda^{*}{ }_{\mathrm{m}}\left(\mathrm{S} . \mathrm{cm}^{2} / \mathrm{mol}\right)\end{array}$ & $\begin{array}{c}\text { Cation: Anion } \\
\text { Ratio }\end{array}$ & $\begin{array}{c}\text { Number of } \\
\text { Ions }\end{array}$ \\
\hline Methanol & - & - & 0 \\
\hline $\mathrm{CuSO}_{4} \cdot 5 \mathrm{H}_{2} \mathrm{O}$ & 8 & $1: 1$ & 2 \\
\hline $\mathrm{FeSO}_{4} \cdot 7 \mathrm{H}_{2} \mathrm{O}$ & 16 & $1: 1$ & 2 \\
\hline $\mathrm{Cu}\left(\mathrm{NO}_{3}\right)_{2} \cdot 5 \mathrm{H}_{2} \mathrm{O}$ & 100 & $2: 1$ & 3 \\
\hline $\mathrm{Co}\left(\mathrm{NO}_{3}\right)_{2} \cdot 6 \mathrm{H}_{2} \mathrm{O}$ & 130 & $2: 1$ & 3 \\
\hline $\mathrm{Cr}\left(\mathrm{NO}_{3}\right)_{3} \cdot 6 \mathrm{H}_{2} \mathrm{O}$ & 160 & $3: 1$ & 4 \\
\hline $\mathrm{Cu}(\mathrm{II})-\mathrm{SB}$ & 6 & $1: 1$ & 1 \\
\hline
\end{tabular}

From the results of infrared data, the complex undergoes a shift in functional group absorption. The infrared spectra are shown in Fig.-7. IR spectrum of $\left[\mathrm{Cu}(\mathrm{SB})_{2}\right] \mathrm{SO}_{4} \cdot \mathrm{H}_{2} \mathrm{O}$ showed a shift in $\mathrm{C}=\mathrm{N}_{\text {azomethine }}$ and $\mathrm{C}=\mathrm{N}_{\text {thiazole }}$ groups' absorption. There was a shift of $\mathrm{C}=\mathrm{N}_{\text {azomethine }}$ and $\mathrm{C}=\mathrm{N}_{\text {thiazole }}$ absorption from 1601 and $1558 \mathrm{~cm}^{-1}$ in SB to 1648 and $1546 \mathrm{~cm}^{-1}$ in the complex, respectively. This shift indicates the coordination 
of the bidentate Schiff base ligands through the $\mathrm{C}=\mathrm{N}_{\text {azomethine }}$ and $\mathrm{C}=\mathrm{N}_{\text {thiazole }}$ functional groups. The appearance of $\mathrm{Cu}-\mathrm{N}$ absorption also indicates that the ligand was coordinated to the metal via the $\mathrm{N}$ donor atom. The presence of $\mathrm{O}-\mathrm{H}$ absorption at $3299 \mathrm{~cm}^{-1}$ also indicates the presence of $\mathrm{H}_{2} \mathrm{O}$ in the complex.

\section{Electronic Spectra}



Fig.-7: FTIR Spectra of SB and $\mathrm{Cu}(\mathrm{II})-\mathrm{SB}$

Complex $\left[\mathrm{Cu}(\mathrm{SB})_{2}\right] \mathrm{SO}_{4} \cdot \mathrm{H}_{2} \mathrm{O}$ has one peak absorption at $778 \mathrm{~nm}$ with a relatively small value of molar absorptivity $(\varepsilon)(<1000 \mathrm{~L} / \mathrm{mol} \mathrm{cm})\left(\varepsilon=48 \mathrm{~L} / \mathrm{mol} . \mathrm{cm} ; v=12,853.47 \mathrm{~cm}^{-1}\right)$. This absorption can be indicated as a d-d transition, namely the ${ }^{2} \mathrm{~B}_{1 \mathrm{~g}} \rightarrow{ }^{2} \mathrm{~A}_{1 \mathrm{~g}}$ transition, which has a smaller wavelength shift than the $\mathrm{CuSO}_{4} \cdot 5 \mathrm{H}_{2} \mathrm{O}$ metal absorption $\left(823 \mathrm{~nm} ; \varepsilon=32 \mathrm{~L} / \mathrm{mol} . \mathrm{cm} ; v=12,150.66 \mathrm{~cm}^{-1}\right)$. This shift indicates that $\mathrm{SB}$ has a greater ligand strength than $\mathrm{H}_{2} \mathrm{O}$. Cu(II) complex with the basic ligand Schiff salicylaldehyde derivative has an absorption peak of $622 \mathrm{~nm}$ with a molar absorptivity value (E) $80 \mathrm{~L} / \mathrm{mol}$.cm which is indicated as a d-d transition. ${ }^{24}$ Square planar complexes of $\mathrm{Cu}$ (II)-sulfisoxazole and $\mathrm{Cu}$ (II)-sulfanilamide have one peak absorption at $793 \mathrm{~nm}$, respectively, with low molar absorptivity. ${ }^{25}\left[\mathrm{Cu}(\mathrm{SB})_{2}\right] \mathrm{SO}_{4} \cdot \mathrm{H}_{2} \mathrm{O}$ is proposed to form square planar geometry.

\section{Magnetic Moment}

$\left[\mathrm{Cu}(\mathrm{SB})_{2}\right] \mathrm{SO}_{4} \cdot \mathrm{H}_{2} \mathrm{O}$ has an effective magnetic moment value of 2.07 B.M. The complexes with the effective magnetic moment of 1.73-2.12 B.M. are paramagnetic with 1 unpaired electron ${ }^{26}$. These results also indicate that there is no interaction or bonding between $\mathrm{Cu}$ metals. The effective magnetic moment value smaller than 1.73 will produce a complex with diamagnetic properties. ${ }^{27} \mathrm{Cu}$ (II)-sulfisoxazole complex has an effective magnetic moment value of 2.12-215 B.M and square planar geometry. ${ }^{25}$ Therefore, $\left[\mathrm{Cu}(\mathrm{SB})_{2}\right] \mathrm{SO}_{4} \cdot \mathrm{H}_{2} \mathrm{O}$ is paramagnetic and estimated to have a square planar geometry. ${ }^{28-29}$ From the characterization above, the proposed structure of the complex is shown in Fig.-8.

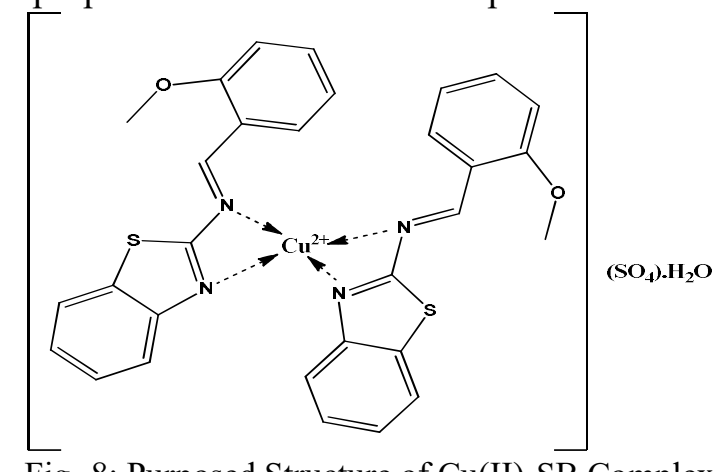

Fig.-8: Purposed Structure of Cu(II)-SB Complex 
RASĀYAN J. Chem.

Vol. 14 | No. 3 |2116-2124| July - September | 2021

\section{Antibacterial Test}

The antibacterial activity test was carried out by using the disc diffusion method or disc paper diffusion. DMSO was used as a negative control because it did not provide an inhibitory zone and could dissolve the sample, while for positive control, several antibiotics were used. The results of the bacterial inhibition zone are shown in Table-3.

Table-3: Average Inhibitory Zone

Staphylococcus aureus

Inhibition Zone Diameter (mm)

\begin{tabular}{|c|c|c|c|c|c|c|c|}
\hline \multirow[b]{2}{*}{ Compound } & \multicolumn{5}{|c|}{ Concentration $(\mu \mathrm{g} /$ disk $)$} & \multicolumn{2}{|c|}{ Control } \\
\hline & 15 & 30 & 45 & 60 & 75 & $\begin{array}{c}\text { DMSO } \\
(-)\end{array}$ & $\begin{array}{c}\text { Antibiotic } \\
(+)^{*}\end{array}$ \\
\hline $\mathrm{CuSO}_{4} \cdot 5 \mathrm{H}_{2} \mathrm{O}$ & - & 7.32 & 7.41 & 7.60 & 7.80 & - & 24.40 \\
\hline SB & 6.45 & 6.51 & 6.67 & 6.78 & 6.92 & - & 24.40 \\
\hline $\mathrm{Cu}(\mathrm{II})-\mathrm{SB}$ & 6,95 & 7.4 & 7.56 & 7.70 & 8.25 & - & 24,40 \\
\hline \multicolumn{8}{|c|}{$\begin{array}{l}\text { Staphylococcus epidermidis } \\
\text { Inhibition zone diameter (mm) }\end{array}$} \\
\hline $\mathrm{CuSO}_{4} \cdot 5 \mathrm{H}_{2} \mathrm{O}$ & - & - & - & - & - & - & 24.40 \\
\hline SB & - & - & - & 6.67 & 6.68 & - & 24.40 \\
\hline $\mathrm{Cu}(\mathrm{II})-\mathrm{SB}$ & 6.36 & 6.47 & 6.72 & 6.94 & 7.12 & - & 24.40 \\
\hline
\end{tabular}

Escherichia coli

Inhibition zone diameter $(\mathrm{mm})$

\begin{tabular}{c|c|c|c|c|c|c|c}
\hline $\mathrm{CuSO}_{4} \cdot 5 \mathrm{H}_{2} \mathrm{O}$ & 6.12 & 6.45 & 6.58 & 6.83 & 6.87 & - & 28.25 \\
\hline $\mathrm{SB}$ & - & 6.46 & 6.57 & 6.64 & 6.73 & - & 28.25 \\
\hline $\mathrm{Cu}(\mathrm{II})-\mathrm{SB}$ & 6.82 & 6.92 & 7.12 & 7.23 & 7.33 & - & 28.25 \\
\hline \multicolumn{7}{c}{ Pseudomonas aeruginosa } \\
\hline \multicolumn{7}{c|}{ Inhibition zone diameter (mm) } \\
\hline $\mathrm{CuSO}_{4} \cdot 5 \mathrm{H}_{2} \mathrm{O}$ & - & - & - & - & - & - & 19.93 \\
\hline $\mathrm{SB}$ & - & - & - & - & - & - & 19.93 \\
\hline $\mathrm{Cu}(\mathrm{II})-\mathrm{SB}$ & 8.18 & 8.35 & 8.63 & 8.64 & 8.84 & - & 19.93 \\
\hline
\end{tabular}

* Antibiotics for St. aureus: vancomycin; St. epidermidis: vancomycin; P. aeruginosa: gentamycin; E. coli: chloramphenicol;

For Staphylococcus aureus bacteria, it was found that at the highest concentration of $75 \mu \mathrm{g} / \mathrm{disk}$, the ligand inhibition zone was very low and tended not to inhibit bacterial growth. While at the same concentration, the complex inhibition zone was higher $(8.25 \mathrm{~mm})$. In the Staphylococcus epidermidis bacteria, the inhibition zone of bacteria on $\mathrm{CuSO}_{4}$ metal was not visible, and only on the SB showed the inhibition zone at the highest concentration $75 \mu \mathrm{g} /$ disk. Whereas in the complex, there was an inhibition zone, $7.12 \mathrm{~mm}$, with quite low values at the highest concentrations. In Escherichia coli, SB's inhibition zone began to appear at a concentration of $45 \mu \mathrm{g} / \mathrm{disk}$ and continued to increase at the highest concentration. However, this ligand inhibition zone's results were still low compared to the complex inhibition zone, which had begun to appear to inhibit at a concentration of $15 \mu \mathrm{g} / \mathrm{disk}$ and continued to increase with increasing concentrations, $7.33 \mathrm{~mm}$ at a concentration of $75 \mu \mathrm{g} /$ disk. In Pseudomonas aeruginosa bacteria, the inhibition zone on $\mathrm{CuSO}_{4}$ metal and $\mathrm{SB}$ was not visible, while in the complex, the inhibition zone was seen at the lowest concentration to the highest concentration with the inhibition zone at a concentration of $75 \mu \mathrm{g} / \mathrm{disk}$ of $8.84 \mathrm{~mm}$.

The results in Table-3 show that SB and $\mathrm{CuSO}_{4} \cdot 5 \mathrm{H}_{2} \mathrm{O}$ have a low bacterial inhibition zone. Meanwhile, the complex showed a significant increase in antibacterial activity. This improvement may be due to copper complexing with $\mathrm{C}=\mathrm{N}$, which causes a decrease in polarity and an increase in copper ions' lipophilicity so that the $\mathrm{Cu}$ (II)-SB can easily enter the bacterial cell membrane. ${ }^{30}$ It can damage bacterial metabolism. Another thing that may also influence is the nature of $\mathrm{Cu}$ metal, which can kill bacterial cells at various concentrations due to the electron affinity for $\mathrm{Cu}$ metal ions. ${ }^{31}$ 
RASĀYAN J. Chem.

Vol. 14 | No. 3 |2116-2124| July - September | 2021

\section{CONCLUSION}

SB was successfully synthesized by reacting o-anisaldehyde and 2-aminobenzothiazole in methanol at a 1: 1 mole ratio with glacial acetic acid as catalyst. The ligand analyzed with ${ }^{1} \mathrm{H}-\mathrm{NMR}$ showed the loss of chemical shift from proton amines and the appearance of the chemical shift of azomethine protons. Based on ${ }^{13} \mathrm{C}-\mathrm{NMR}$ data, the number of $\mathrm{C}$ atoms also corresponded to the expected ligand. The copper(II) complex with SB was successfully synthesized with the maximum wavelength in the UV-Vis spectrum of $778 \mathrm{~nm}$. A possible complex formula was $\left[\mathrm{Cu}(\mathrm{SB})_{2}\right] \mathrm{SO}_{4} \cdot \mathrm{H}_{2} \mathrm{O} \cdot \mathrm{Cu}(\mathrm{II})-\mathrm{SB}$ complex was electrolyte, paramagnetic, and was estimated to have a square planar geometry via $\mathrm{C}=\mathrm{N}$ azomethine and $\mathrm{C}=\mathrm{N}$ thiazole groups of SB. $\mathrm{Cu}(\mathrm{II})-\mathrm{SB}$ complex has slightly higher antibacterial activity than copper(II) and SB.

\section{ACKNOWLEDGMENT}

The authors express acknowledgments to Sebelas Maret University for financial support through Hibah Penelitian Fundamental PNBP UNS.

\section{REFERENCES}

1. B. Amali, Irudayaraj, M. Palsamy, V. Vijayakumar, N. Indra, J. Rajesh, and G. Rajagopal, Journal of Molecular Structure, 1183, 342(2019), https://doi.org/10.1016/j.molstruc.2019.02.005

2. B. Mustafa and N. Turan, Journal of Molecular Structure, 1205(II),127542(2020), https://doi.org/10.1016/j.molstruc.2019.127542

3. R. Mohapatra, A. Sarangi, M. Azam, M. El-ajaily, M. Zahan, S. Patjoshi, and D. Dash, Journal of Molecular Structure, 1179, 65(2019), https://doi.org/10.1016/j.molstruc.2018.10.070

4. G. İlyas, Inorganica Chimica Acta, 495, 1(2019), https://doi.org/10.1016/j.ica.2019.119027

5. V. Radha, S. Kirubavathy and S. Chitra, Journal of Molecular Structure, 1165, 246(2018), https://doi.org/10.1016/j.molstruc.2018.03.109

6. S. Prasad, R. Pillai, S. Armaković, and S. Armaković, Inorganica Chimica Acta, 486, 698(2019), https://doi.org/10.1016/j.ica.2018.11.045

7. H. Keypour, M. Aidi, M. Mahmoudabadi, R. Karamian, M. Asadbegy, and R. William, Journal of Molecular Structure, 1198, 126666(2019), https://doi.org/10.1016/j.molstruc.2019.06.024

8. A. Fatemeh, A. Faraji, S. Molaeian, M. Fall, and R. Butcher, Journal of Molecular Structure, 1204, 127483(2020), https://doi.org/10.1016/j.molstruc.2019.127483

9. S. S. Kolate, G. P. Waghulde, and C. J. Patil, Rasayan Journal of Chemistry, 13(2), 1008(2020), https://doi.org/10.31788/RJC.2020.1325606

10. S. Etaiw, D. El-Aziz, E. El-Zaher, and E. Ali, Spectrochimica Acta - Part A: Molecular and Biomolecular Spectroscopy, 79(5), 1331(2011), https://doi.org/10.1016/j.saa.2011.04.064

11. J. Joseph, and G. Janaki, Journal of Photochemistry and Photobiology B: Biology, 162, 86(2016), https://doi.org/10.1016/j.jphotobiol.2016.06.030

12. N. Mishra, S. Gound, R. Mondal, R. Yadav, and R. Pandey, Results in Chemistry, 1, 100006(2019), https://doi.org/10.1016/j.rechem.2019.100006

13. K. Venkateswarlu, N. Ganji, S. Daravath, K. Kanneboina, K. Rangan, and Shivaraj, Polyhedron, 171, 86(2019), https://doi.org/10.1016/j.poly.2019.06.04

14. B. Iftikhar, K. Javed, M. Khan, Z. Akhter, B. Mirza, and V. Mckee. Journal of Molecular Structure, 1155, 337(2018), https://doi.org/10.1016/j.molstruc.2017.11.022

15. S. Balakrishnan, S. Duraisamy, M. Kasi, S. Kandasamy, R. Sarkar, and A. Kumarasamy, Heliyon, 5, 1687(2019), https://doi.org/10.1016/j.heliyon.2019.e01687

16. J. Do Prado, A. Valdo, F. Martins, R. de Santana, and D. Cangussu, Journal of Molecular Structure, II, 127468(2019), https://doi.org/10.1016/j.molstruc.2019.127468

17. P. Nunes, F. Marques, I. Cavaco, J. Pessoa, and I. Correia, Inorganica Chimica Acta, 507, 119558(2020), https://doi.org/10.1016/j.ica.2020.119558

18. M. Pervaiz, I. Ahmad, M. Yousaf, S. Kirn, A. Munawar, Z. Saeed, A. Adnan, T. Gulzar, T. Kamal, A. Ahmad, and A. Rashid, Spectrochimica Acta Part A: Molecular and Biomolecular Spectroscopy, 206, 642(2019), https://doi.org/10.1016/j.saa.2018.05.057

19. M. Shabbir, Z. Akhter, H. Ismail, and B. Mirza, Journal of Molecular Structure, 1146, 57(2017), https://doi.org/10.1016/j.molstruc.2017.05.127 
RASĀYAN J. Chem.

Vol. 14 | No. 3 |2116-2124| July - September | 2021

20. S. B Rahardjo, T. Saraswati, A. Masykur, N. Finantrena, L. Fatawati, In Proceedings International Conference on Science and Applied Science, 020009(2018), https://doi.org/10.1063/1.5054413

21. H. Syaima, V. Suryanti, S. B Rahardjo, Chiang Mai Journal of Science, 47(6), 1265(2020).

22. F. Sevgi, U. Bagkesici, A. Kursunlu, and E. Guler, Journal of Molecular Structure, 1154, 256(2018), https://doi.org/10.1016/j.molstruc.2017.10.052

23. K. Neelimaa, and D. Kumar, Materials Today: Proceeding,s 5 (1), 26(2018), https://doi.org/10.1016/j.matpr.2017.11.256

24. Z. Albobaledi, M. Hasanzadeh, M. Behzad, and A. Abbasi, Inorganica Chimica Acta, 499, 1(2020), https://doi.org/10.1016/j.ica.2019.119185

25. S. B Rahardjo, Suwarsih, H. Syaima, Rasayan Journal of Chemistry, 13(3), 1701(2020), https://doi.org/10.31788/rjc.2020.1335727

26. S. Tabti, A. Djedouani, D. Aggoun, I. Warad, S. Rahmouni, S. Romdhane, and H. Fouzi, Journal of Molecular Structure, 1155, 11(2019), https://doi.org/10.1016/j.molstruc.2017.10.084

27. R. Borthakur, A. Kumar, A. De, and R. Lal, Arabian Journal of Chemistry, 12 (8), 2192(2019), https://doi.org/10.1016/j.arabjc.2014.12.040

28. K. Mahmood, W. Hashmi, H. Ismail, B. Mirza, B. Twamley, Z. Akhter, I. Rozas, and R. Baker, Polyhedron, 157, 326(2019), https://doi.org/10.1016/j.poly.2018.10.020

29. D. Surendra, V. Thangaraj, and A. Paul Raj, Arabian Journal of Chemistry, 9, 31(2016), https://doi.org/10.1016/j.arabjc.2011.07.016

30. B. Kumari, S. Adhikari, J. Matalobos, and D. Das, Journal of Molecular Structure, 1151, 169(2018), https://doi.org/10.1016/j.molstruc.2017.09.031

31. M. Antonijević-Nikolić, J. Antić-Stanković, B. Dražić, and S. Tanasković, Journal of Molecular Structure, 1184, 41(2019), https://doi.org/10.1016/j.molstruc.2018.10.027

[RJC-6378/2021] 